\title{
College English Teaching Reform of China under the External Propaganda Policy
}

\author{
Xiaoli Zhang \\ Shandong Technology and Institute University \\ Yantai, China
}

\begin{abstract}
It is one of China's important national strategies to build a cultural power and to introduce its traditional culture to the world. To strengthen the external propaganda will enhance China's cultural soft power and greatly contribute to the national strategic objective. China's external propaganda has to fully aware of the international environment and keep up with the times. Its success can only be assured with timely strategic adjustments and multichannel for communication. The globalization and information modernization open up a favorable new situation for China's external propaganda, for it does not only expand the front but also enrich the Channels. Faced with the new situation, China's publicity has to grab the opportunity and absorb the ordinary citizens, especially the energetic college students, into its propaganda front and take good advantage of the interpersonal communication to spread the good voice of China. This puts forward higher requirements for college English Teaching. China's College English Teaching has to deepen its reform centering around teaching materials, teaching mode and teaching staff under the guidance of the propaganda's three principles. China's English teaching is expected to contribute to the establishment of China's international image.
\end{abstract}

Keywords —external propaganda; cultural soft power; college English reform

\section{INTRODUCTION}

It is one of China's important national strategies to build a cultural power and to introduce its traditional culture to the world. To strengthen the external propaganda will enhance China's cultural soft power and greatly contribute to the national strategic objective. Xi Jinping, the President of the state has already pointed out that the success of China's external propaganda comes with innovations and a series of elaborate plans under the new situation. President Xi's speech does not only affirm the national strategic position of China's external propaganda but also puts forward new requirements for it. China's external propaganda, as the primary means of shaping and disseminating the national image, has to be fully aware of the international environment and keep up with the times. Its success can only be assured with timely strategic adjustments and multichannel for communication.

The thesis is part of two projects supported by Shandong Province Foundation for Social Science Planning and the project number is $11 \mathrm{CWZJ} 38$ and 14CWXJ50 respectively.

\section{THE NEW SiTUATION FOR CHINA's EXTERNAL PROPAGANDA}

China has all along been considering the foreign elites and governments as the main target of its external propaganda and the nation's official media has been being its main way of communicating with the foreign world. Such a single mode of publicity, however, fails to achieve the desired results. China has long been misunderstood in some aspects by the international community [Shen Yamei, 2011: 11-12]. The lack of cooperation between the government and the public has long been a hindering factor [Wu Youfu, 2012]. Fortunately, globalization and information modernization open up a favorable new situation for China's external propaganda. For one thing, the trend of globalization makes every Chinese citizen the possible disseminator of the traditional culture and expands the front of China's publicity. Annual statistics released by the World Tourism Organization show that in 2015 the number of Chinese traveling abroad reached a million, ranking the world's first. Meanwhile, there are a growing number of foreigners crowding into China. International Organization for Migration keeps a precise count of foreigners living in China. According to their report released in Geneva in 2013, the number has increased by $35 \%$ within 10 years. The integration of peoples places the sacred duty in the hands of every Chinese citizen to outreach the country's culture. For another, the development of the Information and networks technology has exceedingly enriched the channels of the publicity and calls for more people to be part of the national propaganda system. The era of personal media has pushes every Chinese citizen to be the window to the world. The diversity of disseminators and communication channels are bound to create favorable conditions for China's external propaganda.

Bernard Vayer Bernard, the French News scientist, claims that interpersonal communication is the most favorable form of human communications. Compared with the government's single and cold one-way dissemination, two-way communication is more acceptable and convincible. In addition, daily exchanges between people, to some extent, will allow more foreigners to have close contact with Chinese culture so as to expand the scope of China's cultural propaganda. Where there are foreigners there should be external propaganda [Eppste, Lin Maosun, Shen Suru, 2000: 2]. Therefore, it is time for china to reform and innovate its 
conventional ways of external propaganda. China should grab the opportunity and motivate every possible disseminator to introduce its national culture. The interpersonal communication with the participation of every Chinese citizen will greatly enhance the effects of China's external propaganda and display a real China to the world. A wholly new system of external propaganda which keep will keep its pace with the changing national situation and social surroundings is extremely expected.

\section{College English TeACHING SHOULd Play AN ACTIVE ROLE IN CHINA's EXTERNAL PROPAGANDA}

New situation calls for timely strategic adjustments and innovation. To unite ordinary citizens, China has to attach great importance to its college English teaching. This is because the status of English as an international language is difficult to change in a short time. As the primary medium of communication in the world community, English occupies a very important position in the outreach of Chinese culture, even being the most direct factor in determining the effect of propaganda. After all, languages carry cultures, and a correct language conveys a correct culture. What's more, the objects of college English teaching are the groups that are most active and energetic and they account for a large proportion of Chinese population. According to the Chinese Bureau of Statistics, in 2015 the number of Chinese college students has reached up to 37 million. With the world's largest number of college students, China holds a tremendous power in hand. Therefore, it is advisable for China to make good use of the power and guide them to serve as the main force of its external propaganda. Viewed from this perspective, college English teaching is given a much tougher task. In the face of new era, college English teaching should conform to the trend and endeavor to deepen its reform so as to better accomplish the glorious mission entrusted by the state.

\section{ADHERING TO THE THREE PRINCIPLES OF CHINA'S EXTERNAL PROPAGANDA AND DEEPENING THE REFORM OF College ENGLish TEACHING}

Huang Youyi, the Secretary-General of China Translation Association proposes three principles to which China's external propaganda has to adhere. According to him, China's publicity in the world community has to be close to the reality of China's development, satisfy the foreigners' curiosity in China and go in line with foreigners' thinking habits [Huang Youyi, 2004]. As an important link of the propaganda system, China's college English teaching should also follow the guidance of the three principles and deepen its reform, improving its teaching materials, mode, and teaching ability.

\section{A. Revising English Text Book and Increasing Native Culture}

As possible disseminators of the national culture, college students are supposed to work harder. This is because they should not only have a good understanding of the national history and spirit, but also should be good at English. To convey the Chinese culture by means of English language put forward higher requirements for college students, and meanwhile, pushes college English teaching to make timely adjustments. China's college English teaching has to embrace both the education of traditional culture and that of English language skills. Only the students who are armed with strong language skills and higher humanity can successfully and accurately spread the voice of China.

Textbooks, as one important part of teaching activities, are the center of the class which determines teaching content and the depth and breadth of the knowledge. A good text book is the key to the success of the college English teaching reform. English textbooks have to match the new target to cultivate students with the ability of international communication. The current college English textbooks, however, all miss the part of native culture. English classes have been totally occupied with western culture, history and art. The education of Chinese culture is almost completely lost in the process of English language teaching, which seriously affecting students' understanding of the native culture and hence resulting in a serious "Chinese Culture Aphasia". The examination form of translation in College English Test, Band4, has already changed from sentence translation to paragraph translation. The content covers Chinese history, culture, society and economy. This is really a good attempt; however, the reform of English teaching materials is relatively backward. The blank of proper authoritative teaching materials adds a further completion of teaching activities and reduces the teaching effects. What's worse, without the official definition for terms of Chinese Characteristics, the accuracy of teaching content fails to be guaranteed. These factors will seriously affect students' ability to spread the national culture.

Therefore, to revise English teaching textbooks should become a top priority of China's English teaching reform. The editors of China should face the challenge and reform. It is essential to add native Chinese content into English textbooks. English textbooks should be made a forum for the exchanges of Eastern and Western cultures, through which students do not only see the world but also learn how to introduce China to the world. In addition, the perfection of teaching material system is also a necessity. The construction of teaching material system should be multidimensional, ranging from listening, speaking, reading, writing and translating. The scientific teaching materials and systems can strengthen comprehensive infiltration of the native culture into English teaching and build a solid foundation for China's external propaganda.

\section{B. Reforming the Teaching Mode and Improving the Education Mechanism}

A teaching mode is the reflection of educational theories and concepts. The concepts of education determine teaching modes and teaching modes set the directions for teaching behaviors. Another core element that determines the design of teaching modes is the instructional objective. Every teaching mode is all aimed at an established teaching objective. China's College English teaching are now facing a new situation that China seeks to enhance its national cultural soft power. Under such a background, both the 
concept and objective of China's college English Teaching should make timely adjustments. As mentioned above, China's college English teaching is supposed to have the three principles of external propaganda as its new teaching guidance and have the training of qualified personnel of publicity as its new instructional objective. Therefore, it is urgent to establish a new teaching mode to match with it. The reform of College English teaching mode should proceed from the following aspects.

Firstly, it needs to strengthen students' patriotism education and establish their sense of ownership over the nation. A series of elaborate activities will be greatly helpful to improve students' national consciousness and their patriotic enthusiasm, such as monthly activities with the theme of patriotism, contests of patriotic knowledge, book fairs of national culture and lectures of national history, and the forth. Such activities will not only enhance students' national pride, but also lead them to obtain the cultural identity, with which the voice of China will be better spread. Secondly, it still needs to enrich English teaching methods and expand English teaching and learning channels. To face the challenge, China's traditional single college English teaching mode has to be reformed. An information channel, including both paper and electronic reading materials, should be constructed. Teachers should guide their students to make good use of the networks and pay close attention to the news home and abroad. Apart from language skills, a possible disseminator should also have the ability of dialectical thinking. A mind with calm and wisdom will convey the objective and truthful information. Thirdly, the evaluation mechanism should be further perfected and added the comprehensive assessment based on the test of cultural translation. The relative daily evaluation and examination can be used as a means to motive students to adjust their learning strategy and contents. And then, profound cultural knowledge and solid translation skills will be assured.

\section{Improving the Professional Level of Teaching Staff}

A team of English teachers with high cultural quality and teaching ability is a key link of teaching reform and much concern the effects of China's external propaganda. When China's culture is conveyed, it should be carried by the languages that foreigners can understand. Therefore, English teachers must be qualified to lead their students to figure out the subtle differences and characteristics of Chinese and western culture.

The new situation requires English teachers to be equipped with both strong language skills and cross-cultural communication mind. Therefore, on one hand, teachers should firstly feel a great deal of responsibility and accept the mission to improve the quality of the whole nation. They should also adjust their teaching goal form single language teaching to the training of international propaganda skills. All these obligations and responsibilities push China's English teachers to study further. On the other hand, the leaders have to set up the concept of international training of English teachers and further develop the training system. More teachers, especially the young, should be accepted by the training system. The training should be regular and consistent and take good advantage of all possible resources. The training institution can not only invite famous teachers home and abroad to give lectures, but also can encourage teachers to study abroad. The leaders should strengthen international cooperation and exchanges and endeavor to open up more channels for teachers' improvement. Qualified teachers are the prerequisite of qualified disseminators.

\section{Establishing a Perfect Network Learning and Communication Forum}

To successfully fulfill the task of introducing the real China to the world, college students are firstly supposed to know what is happening in China and around the world. Fortunately, the development of information technology brings students a lot of benefits. With the simple fingertip touch, a wealth of information will be instantly available for them to use. To keep a close touch with the fast changing world, 24 Internet connectivity service on campus will be very indispensible. Universities and the related authorities are strongly suggested to consider an increased budget for the construction of the campus networks. Various English learning materials will be included and easily accessible on the campus networks, including domestic and foreign news, Chinese and foreign culture, Chinese and English cultural books and so on. The training of translation skills and practice will be another important part on the campus networks. Web translation communities provide both the teachers and students with good forums on which after-class discussions can be held. Such communication will inspire students to have a profound thinking and encourage them to be more sophisticated and critical. Such rewarding experience will in turn enhance students understanding of translation theories. Take Bulletin Board System (BBS) as an example. China daily BBS is one of the most influential forums within China, which is open to both interpreters and learners. On China daily BBS, there are various sections, such as the section from which students can gain help, the section established especially for the introduction and explanation of new created words and phrases, the section that learners compete and learn with each other and the section from which students will get the directions of famous experts. With a perfect campus network system, it will be convenient for students reach so wonderful materials by which their abilities of translation will be greatly promoted. E.Enhancing Ideological and Political Education.

In 2004, To Enhance the Ideological and Political Education of College Students, the document that was issued by CPC central committee and the State Council, attached great importance with the guidance of college students at the level of their mental modes. The document stresses that college students are valuable talent resources of China. They are the hope of Chinese people and the future of the country. Therefore, it should be on the top of the list that teachers guide college students to establish a correct mental mode. To strengthen the ideological and political education of College Students, to improve their political quality, and to mould them as the successors of the socialism has great and farreaching strategic significance for the construction of the 
well-off society and will assure China an invincible position in the fierce international competition.

The constant and dramatic changes in the international and domestic situations bring the ideological and political education of college students both opportunities and challenges. The fight between the international hostile forces and China on the next generation is more acute and complicated. College students are confronted with the impact of a large number of western cultural thoughts and values. The impact of certain decadent and declining life style on college students is not to be underestimated. With the opening up to the outside world and the further development of the socialist market economy, it appears that China's social and economic composition, organization form, employment, interest relations and distribution tend to be increasingly diverse. The independence, selectivity, variability and diversity of the people's thoughts are increasing day by day. On one hand, this is conducive to college students to establish a sense of self-reliance, innovative awareness, talent awareness, entrepreneurial awareness. On the other hand, the negative effects that it brings also cannot be ignored. Many students appear to have, to some extent, some problems, such as political belief confusion, fuzzy ideals and beliefs, value orientation, weak sense of integrity, lack of social responsibility, the spirit of hard struggle fade, the concept of unity, poor coordination, and even psychological problems.

Faced with the new situation, the ideological and political education has to make timely adjustment and take measures to make some reforms. But, in some places, departments and school leaders pay less attention to the ideological and political education of college students. The joint efforts of the whole society to support the ideological and political education of college students have not yet formed. The effectiveness of Ideological and political theory course in schools is not effective. Philosophy and Social Sciences and some teaching materials construction is lagging behind. Ideological and political education and college students' Ideological and practical combination is not well linked to each other. A few schools have neither put the ideological and political education of college students in the first place nor throughout the whole process of education and teaching. The students' management work is not suitable for the development of the situation. The construction of Ideological and political education work team needs to be strengthened urgently. To strengthen and improve the ideological and political education of college students is a very urgent and important task.

The guiding ideology of strengthening and improving the ideological and political education of college students is that teachers and schools should regard the ideal and belief as the core of the education, focusing on patriotism education. College education should be based on the ideological and moral construction, with the comprehensive development of college students as its goal. What's more, advanced education, especially college English education should emancipate its mind, seek truth from facts and advance with the times. It should be students-oriented and should stay close to reality. Efforts to improve the pertinence, effectiveness and appeal of ideological and political education should be made. Only by doing these can college English teaching successfully train the qualified builders and reliable successors of socialism.

\section{CONCLUSION}

In conclusion, the globalization and information modernization offers China a great opportunity to introduce its culture and spirit to the world. China's external propaganda has great significance for the establishment of China's good international image. College English teaching should be great enough to take the glorious mission with active exploration and further reform. It is expected that China's college English teaching will cultivate a team of qualified external propaganda talents.

\section{REFERENCES}

[1] Shen Yamei. Reflections on Western Hot Debate on China's Image [J]. International Studies, 2011(4): 11-12.

[2] Wu Youfu. China's National Image Propaganda from the Perspective of National Strategy [J]. International Review, 2012(4).

[3] Eppste, Lin Maosun, Shen Suru. Calling Attention to Foreign Language in External Propoganda [J]. Chinese Translators Journal, 2000, (6): 2.

[4] Huang Youyi. Adhering to three Principles of China's External Propaganda and Handling the Difficulties Well [J]. Chinese Translators Journal, 2004 (6) 